\title{
RASIO KEPEMILIKAN DAN RASIO EFISIENSI TERHADAP PROFITABILITAS DAMPAKNYA PADA NILAI PERUSAHAAN
}

\author{
Ulfa Ika Putri \\ Azhar Affandi \\ azhar_affandi@yahoo.com \\ Fakultas Ekonomi dan Bisnis, Universitas Pasundan
}

diterima: 29/7/2017; direvisi: 1/11/2017; diterbitkan: 24/2/2018

\begin{abstract}
This study aims to determine the condition of ownership ratio proxyed by equity, the efficiency ratio proxyed by BOPO, profitability ratios proxied with Return On Asset, and company value and to find out how much influence of variable ownership and efficiency to profitability impact on firm value at 18 banking companies listed on the BEI period 2008-2015. This research uses descriptive and verificative methods. Data analysis methods used are multiple regression, multiple correlation, and coefficient of determination. The results showed that the ratio of ownership and efficiency ratio simultaneously and partially have significant effect on profitability. The dominant variable is the ownership ratio. Profitability has a significant effect on corporate value.
\end{abstract}

Keywords: owner ratio; efficiency ratio; profitability ratio; company value

\begin{abstract}
Abstrak
Penelitian ini bertujuan untuk mengetahui kondisi rasio kepemilikan yang diproksikan dengan equity, rasio efisiensi yang diproksikan dengan BOPO, rasio profitabilitas yang diproksikan dengan Return On Asset, dan nilai perusahaan serta untuk mengetahui seberapa besar pengaruh variabel kepemilikan dan efisiensi terhadap profitabilitas dampaknya pada nilai perusahaan pada 18 perusahaan perbankan yang terdaftar di BEI periode 2008-2015. Penelitian ini menggunakan metode deskriptif dan verifikatif. Metode analisis data yang digunakan adalah analisis regresi berganda, korelasi berganda, dan koefisien determinasi. Hasil penelitian menunjukkan bahwa rasio kepemilikan dan rasio efisiensi secara simultan maupun parsial berpengaruh signifikan terhadap profitabilitas. Variabel yang berpengaruh dominan adalah rasio kepemilikan. Profitabilitas berpengaruh signifikan terhadap nilai perusahaan.
\end{abstract}

Kata Kunci : rasio kepemilikan; rasio efisiensi; rasio profitabilitas; nilai perusahaan 


\section{PENDAHULUAN}

Krisis yang terjadi sejak pertengahan tahun 1997 telah berakibat sangat berat bagi perekonomian nasional. Krisis keuangan global yang terjadi pada tahun 2008 pun telah mengangkat kembali perdebatan tentang kehadiran pihak asing dalam sektor perbankan. Hal ini antara lain dipicu pengalaman negara-negara di Eropa Di awal orde baru, Presidium Kabinet Ampera memberikan instruksi Menteri Keuangan dan Gubernur Bank Sentral untuk memberikan izin usaha kepada beberapa bank asing untuk beroperasi di Indonesia. Keberadaan kantor cabang bank asing di Indonesia telah melalui proses sejarah yang panjang.

Berdasarkan Undang-Undang No.10 Tahun 1998 yang merupakan perubahan atas Undang-Undang No. 7 Tahun 1992 tentang perbankan, Bank adalah badan usaha yang menghimpun dana dari masyarakat dalam bentuk simpanan dan menyalurkannya kepada masyarakat dalam bentuk kredit atau bentuk-bentuk lainnya dalam rangka meningkatkan taraf hidup rakyat banyak.

Perusahaan perbankan yang ada di Indonesia meliputi bank persero, bank umum swasta nasional devisa, bank umum swasta nasional non devisa, bank pembangunan daerah, bank campuran, dan bank asing. Kesehatan perusahaan perbankan yang go public di Indonesia dapat dilihat dari kinerja perbankan dalam laporan keuangan dan tahunan yang tercatat di Bursa Efek Indonesia (BEI).

Setiap perusahaan pasti mempunyai tujuan jangka panjang dan jangka pendek. Tujuan jangka pendek yaitu mendapatkan laba maksimal dengan sumber daya yang ada, sementara dalam jangka panjang tujuan utama perusahaan adalah memaksimalkan nilai perusahaan. Nilai perusahaan ini akan menunjukkan kemakmuran pemegang saham, nilai perusahaan yang tinggi menunjukkan kemakmuran pemegang saham juga tinggi.

Nilai perusahaan ditentukan oleh profitabilitas. Profitabilitas adalah kemampuan perusahaan memperoleh laba. Menurut Pandu (2008), kinerja perbankan dapat diukur dengan menggunakan ratarata tingkat bunga pinjaman, rata-rata tingkat bunga simpanan, dan profitabilitas perbankan. Lebih lanjut lagi dalam penelitiannya menyatakan bahwa tingkat bunga simpanan merupakan ukuran kinerja yang lemah dan menimbulkan masalah, sehingga dalam penelitiannya diisimpulkan bahwa profitabilitas merupakan indikator yang paling tepat untuk mengukur kinerja suatu bank.

Ukuran profitabilitas yang digunakan adalah Rate Of Return Equity (ROE) untuk perusahaan pada umumnya dan Return On Asset (ROA) pada industri perbankan. Return on Asset (ROA) memfokuskan kemampuan perusahaan untuk memperoleh earning dalam operasi perusahaan. Dalam Arsitektur Perbankan Indonesia
(2004), kriteria yang dikeluarkan Bank Indonesia untuk sebuah bank bisa menjadi bank jangkar (anchor bank) memiliki rasio Return On Asset (ROA) minimal $1,5 \%$.

Alasan dipilihnya rasio kepemilikan yang diproksikan dengan equity dan rasio efisiensi yang diproksikan dengan BOPO dikarenakan kedua variabel ini merupakan variabel yang mempengaruhi laba atau profitabilitas dimana profitabilitas yang diproksikan ROA yang dapat menunjukkan tingkat profitabilitas perusahaan perbankan sebagai variabel terikat karena ROA merupakan rasio antara laba sebelum pajak terhadap total assets. ROA yang semakin besar, menunjukkan kinerja perusahaan/bank semakin baik, karena tingkat pengembalian (return) semakin besar. Oleh karena itu, ROA merupakan rasio yang tepat digunakan untuk mengukur efektivitas perusahaan/bank dalam menghasilkan keuntungan dengan memanfaatkan aktiva yang dimilikinya. Semakin besar profitabilitas akan mendorong investor untuk melakukan pembelian saham, sehingga kondisi ini akan menaikkan harga saham sehingga profitabilitas akan mempengaruhi nilai perusahaan secara keseluruhan.

\section{METODE}

Metode penelitian yang digunakan dalam penelitian ini adalah metode deskriptif dan verifikatif. Metode penelitian deskriptif adalah suatu metode penelitian yang dilakukan dengan tujuan utama untuk membuat gambaran atau deskripsi tentang suatu keadaan secara objektif. Masing-masing variabel tersebut dicari nilainya kemudian dijelaskan perkembangannya secara deskriptif. Metode desktiptif digunakan untuk mengetahui tingkat equity dan BOPO pada industri perbankan tahun 2008-2015.

Penelitian ini menggunakan empat variabel yang terdiri dari dua variabel bebas yaitu rasio kepemilikan yang diproksikan dengan equity, rasio efisiensi yang diproksikan dengan BOPO dan satu variabel intervening yaitu profitabilitas yang diproksikan dengan ROA, serta satu variabel nilai perusahaan yang diukur dengan Tobin's Q sehingga dapat diambil suatu analisis dengan menggunakan ukuran-ukuran statistik yang berhubungan dengan data empiris. Metode verifikatif digunakan rasio kepemilikan yang diproksikan dengan equity dan rasio efisiensi yang diproksikan dengan BOPO terhadap ROA terhadap nilai perusahaan pada 18 Perusahaan Perbankan yang Terdaftar di Bursa Efek Indonesia Periode 2008-2015.

\section{HASIL DAN PEMBAHASAN}

Data yang digunakan dalam penelitian ini adalah data sekunder dari perusahaan perbankan pada Bursa Efek Indonesia selama 8 tahun yaitu dari tahun 
2008 sampai dengan tahun 2015 yang berjumlah 18 perusahaan perbankan. Variabel yang diteliti dalam penelitian ini adalah equity dan Biaya Operasional terhadap Pendapatan Operasional (BOPO) sebagai variabel independen dan Return On Assets sebagai variable dependennya dengan menggunakan mix method (metode kuantitatif dan metode kualitatif). Hasil penelitian yang telah dilakukan menggunakan program SPSS 21.0 for windows dengan pengujian hasil seperti uji asumsi klasik (uji normalitas, heteroskedastisitas, multikolonieritas, dan autokorelasi), uji regresi linier berganda, pengujian hipotesis, korelasi berganda, dan koefisien determinasi.

Analisis deskriptif adalah metode analisis yang digunakan untuk mencari unsur-unsur, ciri-ciri, dan sifat-sifat suatu fenomena. Metode deskriptif digunakan untuk menjawab rumusan masalah yang bersifat deskriptif, yaitu bagaimana tingkat Nilai Perusahaan, tingkat Return On Asset, tingkat rasio kepemilikan yang diukur dengan equity dan tingkat rasio efisiensi yang diukur dengan Biaya Operasional terhadap Pendapatan Operasional (BOPO) pada 18 perusahaan perbankan yang terdaftar di Bursa Efek Indonesia (BEI) periode $2008-2015$.

Diketahui equity bahwa diperoleh nilai mean sebesar 0,23404247 dengan standar deviasi sebesar 0,280331315 . Nilai standar deviasi yang lebih besar dari nilai mean menunjukkan tingginya variasi antara nilai maksimum dan nilai minimum selama periode pengamatan atau dengan kata lain ada kesenjangan yang cukup bsar equity dari tertinggi dan terendah.

Perkembangan equity 18 perusahaan perbankan yang terdaftar di BEI periode 2008-2015 berada dalam kondisi yang fluktuatif. Pada tahun 2009 equity sempat naik sebesar $0,23 \%$ dan pada tahun 2010 dan 2011 sempat turun sebesar $2,66 \%$, namun pada tahun berikutnya yaitu tahun 2012 equity mengalami peningkatan. Pada tahun selanjutnya yaitu tahun 2013 mengalami penurunan dan selanjutnya pada tahun 2014 dan 2015 mengalami peningkatan lagi. Adanya peningkatan equity mengindikasikan bahwa kemampuan ekuitas perusahaan perbankan dalam membiayai aset yang dimiliki.

BOPO digunakan untuk mengukur tingkat efisiensi kemampuan bank dalam melakukan kegiatan operasinya (Dendawijaya, 2009:120). Semakin tinggi rasio ini menunjukkan semakin tidak efisien biaya operaisonal bank. Rasio biaya operasional digunakan untuk mengukur tingkat efisiensi dan kemampuan bank dalam melakukan kegiatan operasinya.

Rasio kepemilikan yang diproksikan dengan equity secara parsial berpengaruh positif terhadap profitabilitas sebesar 46,1\%. Hal ini dikarenakan equity merupakan salah satu indikator rasio kepemilikan dan kekuatan perusahaan dalam memperoleh keuntungan, sehingga semakin besar equity berpotensi untuk mempengaruhi perolehan profit. Dengan demikian secara ilmu keuangan equity akan mempengaruhi besaran laba yang akan diperoleh.

Rasio efisiensi yang diproksikan dengan BOPO secara parsial berpengaruh negatif terhadap profitabilitas sebesar 14,3\%. Dalam konteks BOPO, indikator ini mengindikasikan tingkat efisiensi perbankan dengan melihat indikasi seberapa besar biaya yang dikeluarkan terhadap pendapatan. Semakin besar biaya yang dikeluarkan pada bank maka akan semakin menunjukkan ketidakefisienan dari operasional perbankan. Dengan demikian, maka perbandingan antara biaya operasional dan pendapatan operasional menunjukkan seberapa besar tingkat pemborosan yang terjadi akibat ketidakefisienan perbankan dalam menjalankan operasional tahunan. Profitabilitas berpengaruh positif terhadap nilai perusahaan sebesar 70,9\%. Hal ini menunjukkan bahwa semakin besar profitabilitas akan mendorong investor untuk melakukan pembelian saham dimana nilai profit menjadi salah satu variabel yang menjadi perhatian investor dalam melakukan aksi beli saham.

Berdasarkan hasil perhitungan bahwa ROA secara parsial berpengaruh signifikan terhadap nilai perusahaan. Artinya semakin besar ROA maka akan semakin meningkatkan nilai perusahaan, sebaliknya semakin kecil ROA maka akan semakin rendah pula nilai perusahaan. Semakin besar profitabilitas akan mendorong investor untuk melakukan pembelian saham, sehingga kondisi ini akan menaikkan harga saham. Kenaikan harga saham akan mendorong nilai kapitalisasi pasar (market capitalization). Nilai pasar dan hutang terhadap Total Aset yang diperoleh dari nilai buku menunjukkan seberapa besar market value share. Dengan demikian dapat dikatakan bahwa nilai profit menjadi salah satu variabel yang jadi perhatian oleh investor dalam melakukan aksi beli saham.

Hasil pengujian ini sesuai dengan penelitian yang dilakukan oleh Husain Al-Omar dan Abdullah AlMutairi (2008), Ana Knezevic dan Dusan Dobromirov (2016); yang menyatakan bahwa rasio kepemilikan dan BOPO berpengaruh secara signifikan terhadap ROA. Perbedaan dengan penelitian terdahulu yaitu pada variabel penelitian karena penulis menggunakan dua variabel pada rasio keuangan yang dua diantaranya sama dengan penelitian Husain Al-Omar dan Abdullah Al-Mutairi (2008). Selain itu penelitian terdahulu dilakukan di BEI pada tahun 2004 - 2011 sementara penulis melakukan penelitian di tahun $2008-2015$. Hal ini menunjukkan bahwa pada dasarnya Return On Asset dipengaruhi oleh rasio kepemilikan dan efisiensi.

Hasil penelitian ini mendukung penelitian yang dilakukan oleh Antoni dan Nasri (2015); Almazari (2014); Dwijayanti dan Naomi (2009); Margaretha dan Marshelly (2013); Riwayanti (2014); Suteja dan Ginting (2014); Jatiningsih O. Musdholifah (2007); Singh (2013); Sohilauw (2016); Sissandhy (2014); Swandayani (2012); Dawood (2014); Wijayanti (2008). 


\section{KESIMPULAN}

Berdasarkan hasil pengujian dan pembahasan yang telah dilakukan dapat menarik kesimpulan (1) Rasio kepemilikan pada 18 perbankan yang terdaftar di Bursa Efek Indonesia periode 2008-2015 cenderung menurun, karena kemampuan ekuitas perusahaan dalam membiayai aset perusahaan cenderung rendah; (2) Rasio efisiensi cenderung menurun, karena biaya operasional yang dikeluarkan jauh lebih kecil jika dibandingkan dengan pendapatan operasional yang didapatkan; (3) Rasio profitabilitas cenderung menurun, karena laba yang menurun setiap tahunnya dengan adanya peningkatan biaya dan total aset; (4) Nilai perusahaan cenderung menurun, karena nilai pasar saham (market value share) dan hutang lebih besar dibandingkan dengan total aset.

Rasio kepemilikan dan rasio efisiensi secara simultan berpengaruh terhadap profitabilitas sebesar $60,4 \%$. Rasio profitabilitas berpengaruh positif terhadap nilai perusahaan sebesar $70,9 \%$.

\section{DAFTAR PUSTAKA}

Almazari, A. A. 2014. Impact of internal factors on bank profitability: Comparative study between Saudi Arabia and Jordan. Journal of Applied finance and banking, 4(1), 125.

Anna Knezevic dan Dusan Dobromirov. 2016. The Determinant of Serbian Banking Industry Profitability. International Journal of Economic Research-Ekonomska Istrazivanja Vol. 29, No. 1, H. 459-474 ISSN 1331-677X.

Antoni, A., \& Nasri, M. 2015. Profitability Determinants of Go-Public Bank in Indonesia: Empirical Evidence after Global Financial Crisis. International Journal of Business and Management Invention Vol 4 issue, 1, 37-46.

Dawood, U. 2014. Factors impacting profitability of commercial banks in Pakistan for the period of (2009-2012). International Journal of Scientific and Research Publications, 4(3), 1-7.

Dendawijaya, Lukman. 2009. Manajemen Perbankan. Jakarta : Erlangga

Dwijayanthy, F., \& Naomi, P. 2009. Analisis Pengaruh Inflasi, BI Rate, dan Nilai Tukar Mata Uang terhadap Profitabilitas Bank Periode 2003-2007.
Jurnal Karisma, 3(2), 87-98.

Husain Al-Omar dan Abdullah Al-Mutairi. 2008. Bank Spesific Determinants of Profitability : The Case of Kuwait. International Journal of Economic and Administrative Sciences : Emerald Insight Volume 24, Issue 2, PP. 20-34.

Jatiningsih, O. Musdholifah. 2007. Pengaruh Variabel Makroekonomi terhadap Indeks Harga Saham Gabungan di Bursa Efek Jakarta. Jurnal Aplikasi Manajemen, 5(1).

Mahardian, Pandu. 2008. Analisi Pengaruh Rasio CAR, BOPO, NPL, NIM, LDR terhadap Kinerja Keuangan Perbankan (Studi Kasus Perusahaan Perbankan yang Tercatat di BEI Periode Juni 2002 - Juni 2007). Tesis Program Studi Magister Manajemen. Semarang : Universitas Diponegoro.

Margaretha, F., \& Marshelly, P. 2013. Faktor-faktor yang Mempengaruhi Kinerja Keuangan Perbankan Indonesia. Jurnal Bisnis dan Akuntansi Vol. 15, No. 2, H. 133-141 ISSN 1410-9875.

Riwayanti, H, E. 2014. Pengaruh Faktor Internal dan Eksternal Bank terhadap Profitabilitas Bank Persero. Jurnal Manajemen. Surabaya: Institut Perbanas.

Singh, K. 2013. Budget Deficit and National Debt: Sharing India Experience (No. 2013-08). The Australian National University, Australia South Asia Research Centre.

Sissandhy, A, K,. 2014. Analisis Pengaruh Kepemilikan Bank, Konsentrasi Kepemilikan, BOPO, LDR, Bank Size, dan CAR terhadap Non Performing Loans. Skripsi. Fakultas Ekonomi dan Bisnis Universitas Diponegoro.

Sohilauw, M. I. S. 2016. Window Dressing sebagai Manifestasi Ekonomi Kapitalis (Analisis Semiotika). Jurnal Ilmiah Bongaya, 5 (XIX), 114-128.

Suteja, J., dan Ginting, G. 2014. Determinan Profitabilitas Bank: Suatu Studi pada Bank yang Terdaftar di Bursa Efek Indonesia. Jurnal Trikonomika Vol. 13, No. 1, H. 62-77 ISSN 1411-514X.

Swandayani, D. M., \& Kusumaningtias, R. 2012. Pengaruh Inflasi, Suku Bunga, Nilai Tukar Valas dan Jumlah Uang Beredar terhadap Profitabilitas pada Perbankan Syariah di Indonesia Periode 20052009. AKRUAL: Jurnal Akuntansi, 3(2), 147-166.

Wijayanti, Tri. 2008. “Analisa Faktor-Faktor yang Mempengaruhi Rentabilitas pada PD. BPR BKK Kabupaten Pati.” Skripsi. Semarang: UNNES. 